\title{
Simplified but Not the Same: Tracing Numeracy Events through Manually Simplified Newsela Articles
}

Ellen C. Agnello

University of Connecticut, ellen.cavanaugh@uconn.edu

Follow this and additional works at: https://digitalcommons.usf.edu/numeracy

Part of the Curriculum and Instruction Commons, Language and Literacy Education Commons, Online and Distance Education Commons, and the Secondary Education Commons

\section{Recommended Citation}

Agnello, Ellen C.. "Simplified but Not the Same: Tracing Numeracy Events through Manually Simplified Newsela Articles." Numeracy 14, Iss. 2 (2021): Article 1. DOI: https://doi.org/10.5038/

1936-4660.14.2.1375 


\title{
Simplified but Not the Same: Tracing Numeracy Events through Manually Simplified Newsela Articles
}

\begin{abstract}
New York-based education startup Newsela has quickly gained popularity with K-12 educators in the six years since its launch. Its website boasts that it serves $90 \%$ of schools in the United States including the 1.5 million teachers they employ and their 20 million students. But what makes it so popular? Teachers are drawn to its Common Core-aligned informational texts which facilitate content-area connections while exposing students to important current events. Likely the most appealing aspect of the platform is its compatibility with differentiation, as it makes available five iterations of each article at varying levels of complexity or Lexile which enables teachers to assign the same article to all students regardless of differences in reading ability. Because all Newsela articles are nonfiction, many utilize mathematical representations to communicate quantitative information, placing demands on students' numeracy competencies. This paper presents the findings of a thematic analysis of the numeracy events found in five Newsela articles at the maximum complexity level and their four simplified equivalents. It explores the various ways in which quantitative information is represented in Newsela articles at differing levels of complexity and what happens to the mathematical representations of quantitative information as text complexity decreases. The analysis reveals that seven different forms of mathematical representation are commonly used in Newsela articles at both ends of the complexity spectrum, at similar rates. As text complexity decreases, authors rely upon qualitative representations of quantitative information, or mathematical words and phrases, more heavily than quantitative representations, which utilize numbers.
\end{abstract}

\section{Keywords}

numeracy, literacy, informational text, reading comprehension, Newsela, simplified text, informational text comprehension, lexile, differentiation, secondary education, English language arts

\section{Creative Commons License}

\section{() (9)}

This work is licensed under a Creative Commons Attribution-Noncommercial 4.0 License

\section{Cover Page Footnote}

Ellen Agnello is a doctoral student in reading education at the University of Connecticut. She holds an M.Ed from Providence College and a B.A. in English from Connecticut College. She is certified by the state of Connecticut to teach secondary English language arts and reading. Previously, she taught English language arts for seven years, which inspired her to return to school to study literacy. She is interested in the intersection of numeracy and literacy, especially the presence of mathematical representations in nonfiction texts, and how these representations impact readability. 


\section{Introduction}

This article explores how Newsela, a popular instructional content platform, represents and modifies quantitative information in manually simplified texts for secondary readers.

\section{Newsela}

Currently, 90 percent of US schools, including the 1.8 million teachers they employ and their 20 million students, use Newsela.com, an online platform that curates Common Core-aligned informational texts for content area reading in grades 2 through 12 (Newsela, n.d.). What makes this New York-based start-up so popular? It boasts a number of appealing traits including a vast text selection, originally published by well-reputed and widely circulated news outlets. Through its pairing of high interest texts and short quizzes, it promises to engage students in nonfiction reading while assisting teachers in progress-monitoring. It also offers disciplinespecific text-sets which provide teachers with dozens of informational texts that align to common curricular topics and themes. Quite possibly its most appealing pledge, however, is its claim to assist teachers in assigning the same text to all students, regardless of differences in reading ability, by providing four manually simplified versions of each article. These versions are written by professional editors who utilize a variety of strategies. In their analysis of the entire corpus of Newsela texts, Scarton et al. (2018) found that Newsela writers simplify texts by compressing complex sentences into shorter, simpler sentences; splitting one complex sentence into many simpler sentences; and turning a complex sentence into a simple sentence by rewriting it using more accessible vocabulary and syntax.

\section{Text Complexity and Simplification}

Though repackaged by Newsela as tech-accessible and free, text simplification and its desirability are nothing new. The McGuffey Readers, published in 1836, were the first series of levelled texts. Over 130 million copies were sold in just 60 years, indicating rapid, widespread popularity as the US population had only reached 76 million by the turn of the century (Fry 2002). The purpose of text simplification is the same as it was then: to make information more accessible to a wider range of readers, such as young children and second language learners, by reducing text complexity but preserving meaning (Chandrasekar and Srinivas 1997; Carroll et al. 1998; Petersen and Ostendorf 2007; Feng 2008; Siddharthan 2014). Siddharthan's (2014) survey of research on text simplification concluded that the manual simplification of texts, which includes strategies such as substituting difficult words and splitting long sentences, was found to facilitate gains in comprehension. Though human writers are responsible for the creation of these simplified texts, their work is often guided by readability formulae (Siddharthan 2014), which 
provide objective numerical scores to books and other texts for the purpose of ranking them by difficulty (Fry 2002). Readability formulae consider two factors when scoring texts: one is syntactic difficulty, which is measured by sentence length, and the other is semantic difficulty, which is determined by word length or frequency (Fry 2002).

\section{Newsela and Lexile}

Newsela writers use MetaMetrix's readability formula, the Lexile Framework, to guide manual simplification efforts. Lexile considers those text characteristics that can be quantified, such as word frequency and sentence length. While consideration of these variables may provide the most expedient prediction of text complexity, many have criticized the Framework for neglecting qualities that also increase complexity but are not easily counted or measured (National Governors Association Center for Best Practices, Council of Chief State School Officers 2010; Chall 2003; Fisher and Frey 2015; Cunningham et al. 2018; Lupo et al. 2019). These include factors such as the structure of the text, its levels of meaning and purpose, the conventionality and clarity of language used, and requisite knowledge demands (Fisher and Frey 2015). Not surprisingly, recent research has found that although Newsela's Lexile rankings may indicate decreased text complexity, qualitative factors known to increase complexity, such as linguistic metaphors, are more often preserved than modified or removed from simplified iterations (Wolska and Clausen 2017).

\section{Newsela, Numeracy, and Text Complexity}

What happens to other text qualities that similarly evade the readability formulae net? Because most Newsela texts are informational, meaning that their purpose is to inform readers about a particular event or phenomenon (National Center for Educational Statistics n.d.), many contain mathematical representations, such as graphs, tables, and statistics, which are used to communicate quantitative information. These mathematical representations contain numeracy events or "occasions in which a numeracy activity is integral to the nature of [readers'] interactions and interpretive processes" (Street and Baker 2006, 201). Numeracy events are situations in which readers must apply mathematical thinking to make inferences. These numeracy events increase text complexity because they require readers to possess and apply mathematical knowledge to manoeuvre between verbal, visual, and numeric sign complexes and synthesize meanings to achieve comprehension (Frith and Prince 2009). One analysis of Newsela texts revealed that selected maximum complexity articles contained, on average, more than a dozen numeracy events, or unique instances requiring readers to activate mathematical thinking while reading to preserve meaning (Agnello and Agnello 2019). In disciplines that do not customarily privilege mathematical thinking, like 
social studies and English language arts (ELA), students are less likely to attend to the numeracy events in the texts they read, even though they may be essential to making meaning. Additionally, teachers of these non-mathematical disciplines may be less cognizant of the demands they place on students (Chapman and Lee 1990).

Though previous research suggests that Newsela's maximum complexity articles place demands on readers' numeracies (Agnello and Agnello 2019), the nature of the numeracy events, and therefore the mathematical knowledge forms essential to making meaning from them, has yet to be explored. Additionally, while it has been found that Newsela articles at the maximum complexity level contain numeracy events, what happens to those numeracy events as the text undergoes manual simplification is also unknown (Agnello and Agnello 2019). Knowledge of the ways in which quantitative information is represented in Newsela articles at varying complexity levels might help teachers of non-mathematical disciplines make these demands visible for students, thus improving comprehension.

This paper presents a qualitative analysis of the numeracy events found in five Newsela articles for the purpose of exploring how quantitative information is represented at varying complexity levels and the methods used by Newsela writers to manipulate the complexity of texts. This study was guided by the following research questions: (1) How is quantitative information represented in Newsela articles at the maximum and minimum complexity levels? (2) What happens to numeracy events as text complexity decreases?

\section{Theoretical Framework: Social Capital Theory}

This research is framed by Bourdieu's (2011) social capital theory because it positions numeracy, or mathematical knowledge and competence, as embodied cultural capital or "long-lasting dispositions of the mind" (Bourdieu 2011, 47). These dispositions are transmitted and acquired in social settings such as schools. Lareau and Lamont (1988) expanded upon Bourdieu's concept of cultural capital, defining it as "institutionalized, i.e., widely shared, high status cultural signals (attitudes, preferences, formal knowledge, behaviors, goods and credentials) used for social or cultural exclusion" (156). Often, embodied capital, unlike economic capital, functions symbolically, meaning it is often recognized as competence, skill, or authority rather than physical capital. Like economic capital, however, cultural capital "yields profits of distinction" (Bourdieu 2011, 49), privileging those who possess it and excluding those who do not. This research presupposes that in our data-obsessed society, those who wield numeracy competencies have greater social power than those who do not (Steen 2001). Because schools act as microcosms of society, the same can be said for the school setting.

Today, quantitative data is one of the most privileged forms of communication, used to convey all kinds of information: health, economic, environmental, and risk 
(Reyna et al. 2009; Cokely et al. 2012; Kahan et al. 2012; Shreiner 2018). Therefore, in order to participate in dominant discourses and make informed decisions, individuals must possess numeracy in addition to literacy knowledge and skills (Steen 2001). Bourdieu's (2011) social capital theory posits that "structural constraints and unequal access to institutional resources" (Dika and Singh 2002, 34) may hinder individuals' ability to assimilate cultural capital, like the skills and competencies that comprise numeracy. Curriculum differentiation, which in the case of Newsela is accomplished through text simplification, may aid teachers in meeting the needs of students with a wide range of skills, but may also inadvertently make "different knowledge available to different groups of students" (Oakes et al. 1992, 570). The current study explores how "power and control translate into principles of communication . . . [that] differentially regulate forms of consciousness with respect to their reproduction" (Bernstein 2000,4) by examining students' access to numeracy events through texts that vary in readability.

\section{Methods Data Collection and Analysis}

The data presented in this study are comprised of the numeracy events found in five articles from two of Newsela's Literature Text Sets. These Text Sets provide ELA teachers with informational texts to supplement traditionally taught literary works. Each article has four simplifications ranging from 520L to $1180 \mathrm{~L}$, or from the third to ninth grade reading levels, roughly. Table 1 displays text titles, available Lexile levels, the originating Text Sets, and the number of numeracy events found in each maximum complexity version. These articles were purposely selected because previous content analysis findings (Agnello and Agnello 2019) revealed that each contained several numeracy events which would aid in the identification of patterns in representation and simplification.

Phase 1. The purpose of the first phase of data collection and analysis was to explore themes related to research question (1): How is quantitative information represented in Newsela articles at the maximum and minimum complexity levels? Thus, data collection began with the identification and isolation of numeracy events in the five texts at Newsela's maximum and minimum Lexile levels. An item qualified as a numeracy event if it consisted of words, mathematical symbols, visuals, or any combination thereof (O'Halloran 2008) necessitating the activation and application of numeracy knowledge and/or skills to achieve comprehension. Essentially, any item that contained quantitative information from which a reader could construct meaning through inference qualified as a numeracy event. In total, 184 numeracy events were identified in the most complex iterations and 68 numeracy events were identified in the least complex iterations. 
Table 1

Newsela Texts Analysed

\begin{tabular}{|c|c|c|c|c|c|c|c|}
\hline \multirow[t]{2}{*}{ Text title } & \multicolumn{5}{|c|}{$\begin{array}{c}\text { Lexile } \\
\text { Article iteration }\end{array}$} & \multirow[t]{2}{*}{ Text set } & \multirow{2}{*}{$\begin{array}{c}\text { Number of } \\
\text { numeracy } \\
\text { events in } \\
\text { "max" articles }\end{array}$} \\
\hline & 1 & 2 & 3 & 4 & 5 & & \\
\hline $\begin{array}{l}\text { In Some States, Low Poverty } \\
\text { Rate Obscures Deeper Despair }\end{array}$ & $\operatorname{Max}$ & 1120 & 1030 & 950 & 710 & $\begin{array}{l}\text { "Black Boy" } \\
\text { by Richard Wright }\end{array}$ & 41 \\
\hline $\begin{array}{l}\text { Oxfam: World's Richest } 85 \\
\text { People Have as Much as Half } \\
\text { the Globe's Population }\end{array}$ & Max & 1180 & 1030 & 930 & 740 & $\begin{array}{l}\text { "Black Boy" } \\
\text { by Richard Wright }\end{array}$ & 36 \\
\hline $\begin{array}{l}\text { How Asian Americans are } \\
\text { Changing the South }\end{array}$ & Max & 1160 & 1000 & 910 & 730 & $\begin{array}{l}\text { "Black Boy" } \\
\text { by Richard Wright }\end{array}$ & 44 \\
\hline $\begin{array}{l}\text { This Superintendent has } \\
\text { Figured out How to Make } \\
\text { School Work for Poor Kids }\end{array}$ & Max & 1120 & 960 & 730 & 520 & $\begin{array}{l}\text { "Thank You M'am" } \\
\text { by Langston Hughes }\end{array}$ & 33 \\
\hline $\begin{array}{l}\text { Time Machine (1902): Children } \\
\text { Working in Pennsylvania Coal } \\
\text { Mines }\end{array}$ & Max & 1080 & 990 & 810 & 550 & $\begin{array}{l}\text { "Thank You M'am" } \\
\text { by Langston Hughes }\end{array}$ & 30 \\
\hline
\end{tabular}

Thematic analysis (Thomas 2006) was applied to the identified numeracy events. This began with open coding the raw data, followed by collecting the codes, crossing out duplications, and organizing what remained into categories (Burnard et al. 2008). Constant Comparative Analysis was also employed to help conceptualize potential relationships between data and to reduce and refine categories (Thorne 2000).

Phase 2. The second phase of data collection and analysis aimed to generate themes to answer research question (2): What happens to numeracy events as text complexity decreases? Upon locating numeracy events in text iterations at the maximum and minimum complexity levels, data collection proceeded with an examination of the three remaining variations of each text for the purpose of finding the modified equivalents of each numeracy event. Rather than focusing on numeracy events in isolation, four pairs of each numeracy event were created, which allowed for an exploration of the strategies authors used at each simplification stage. Doing so produced 736 data points.

Table 2 exhibits three of those data points, each consisting of text excerpts from a more and less complex text iteration. In each, the numeracy events are bolded and italicized. The codes name the manual simplification strategies used on the identified numeracy events as authors moved from a more to less complex version of the text. 
Table 2

Data, Codes, and Categories for Research Question 2

\begin{tabular}{|c|c|c|c|c|}
\hline $\begin{array}{l}\text { Data from } \\
\text { more complex iteration }\end{array}$ & $\begin{array}{l}\text { Data from } \\
\text { less complex iteration }\end{array}$ & Code & Subcategory & Category \\
\hline $\begin{array}{l}\text { The Latino population, by } \\
\text { comparison, increased } 57 \text { percent in } \\
\text { the South. }\end{array}$ & $\begin{array}{l}\text { The Latino population gained } 57 \\
\text { percent in the South. }\end{array}$ & $\begin{array}{l}\text { Substitute } \\
\text { words }\end{array}$ & $\begin{array}{l}\text { Word } \\
\text { manipulation }\end{array}$ & Change \\
\hline $\begin{array}{l}\text { Some states saw their Asian- } \\
\text { American populations nearly double } \\
\text { between } 2000 \text { and } 2010 \text {. }\end{array}$ & $\begin{array}{l}\text { In some states the Asian- } \\
\text { American population nearly } \\
\text { doubled between } 2000 \text { and } 2010 \text {. }\end{array}$ & $\begin{array}{l}\text { Change verb } \\
\text { tense }\end{array}$ & $\begin{array}{l}\text { Word } \\
\text { manipulation }\end{array}$ & Change \\
\hline $\begin{array}{l}\text { An overwhelming majority of the } \\
\text { slate-pickers are boys. }\end{array}$ & $\begin{array}{l}\text { Most of the slate-pickers are } \\
\text { boys. }\end{array}$ & $\begin{array}{l}\text { Substitute part } \\
\text { of speech }\end{array}$ & $\begin{array}{l}\text { Word } \\
\text { manipulation }\end{array}$ & Change \\
\hline
\end{tabular}

Table 3

Definitions and Rates of Occurrence for Seven Numeracy Event Forms Identified in Newsela Texts

\begin{tabular}{|c|c|c|c|c|}
\hline $\begin{array}{l}\text { Numeracy } \\
\text { event forms }\end{array}$ & $\begin{array}{l}\text { Number and } \\
\text { rate of } \\
\text { occurrence in } \\
\text { maximum } \\
\text { complexity } \\
\text { articles (184) }\end{array}$ & $\begin{array}{l}\text { Number and rate } \\
\text { of occurrence in } \\
\text { minimum } \\
\text { complexity } \\
\text { articles (68) }\end{array}$ & Definition & Example \\
\hline Comparisons & $74(40.2 \%)$ & $32(47.1 \%)$ & $\begin{array}{l}\text { Any inequality or } \\
\text { juxtaposition of quantities. }\end{array}$ & $\begin{array}{l}\text { Neighboring Washington, } \\
\text { D.C., was the only place } \\
\text { with a higher rate of deep } \\
\text { poverty. }\end{array}$ \\
\hline Arithmetic & $29(15.8 \%)$ & $10(14.7 \%)$ & $\begin{array}{l}\text { Words or phrases that imply } \\
\text { an arithmetic function: } \\
\text { addition, subtraction, } \\
\text { multiplication, or division. }\end{array}$ & $\begin{array}{l}\text { The Latino population } \\
\text { more than doubled. }\end{array}$ \\
\hline Fractions & $29(15.8 \%)$ & $16(23.5 \%)$ & $\begin{array}{l}\text { Numbers and/or words used to } \\
\text { represent a part to whole } \\
\text { relationship. }\end{array}$ & $\begin{array}{l}\text { Three-fourths hadn't } \\
\text { worked at all. }\end{array}$ \\
\hline Percentages & $22(12.0 \%)$ & $0(0.0 \%)$ & $\begin{array}{l}\text { A quantity followed or } \\
\text { preceded by the words } \\
\text { "percent," "per cent," } \\
\text { "percentage," "rate," or the } \\
\text { percent sign }(\%) .\end{array}$ & $\begin{array}{l}\text { In Maryland, the poverty } \\
\text { rate was just } 13.3 \text { percent. }\end{array}$ \\
\hline $\begin{array}{l}\text { Counts/ } \\
\text { Measures }\end{array}$ & $17(9.2 \%)$ & $4(5.9 \%)$ & $\begin{array}{l}\text { A number that represents an } \\
\text { amount or measurement. }\end{array}$ & $\begin{array}{l}\text { About } 3,000 \text { students are } \\
\text { enrolled in the district. }\end{array}$ \\
\hline Ranges & $11(6.0 \%)$ & $5(7.4 \%)$ & $\begin{array}{l}\text { Two quantities representing } \\
\text { upper and lower limits. }\end{array}$ & $\begin{array}{l}\text { The majority are from } \\
\text { thirteen to sixteen. }\end{array}$ \\
\hline $\begin{array}{l}\text { Slope/ } \\
\text { Correlation }\end{array}$ & $2(1.1 \%)$ & $1(1.5 \%)$ & $\begin{array}{l}\text { Words and/or phrases that } \\
\text { imply a linear relationship } \\
\text { between two quantities. }\end{array}$ & $\begin{array}{l}\text { The number of elderly } \\
\text { Asian-Americans in the } \\
\text { region is increasing } \\
\text { alongside the overall } \\
\text { population. }\end{array}$ \\
\hline
\end{tabular}




\section{Results}

\section{Newsela Authors Utilize Seven Forms to Represent Quantitative Information}

Analysis revealed that Newsela authors utilize seven different mathematical forms when representing quantitative information. These forms, the frequency with which they appear in Newsela texts at the maximum and minimum complexity levels, and examples of each are outlined in Table 3.

\section{Newsela Authors Communicate These Forms Quantitatively and Qualitatively}

Analysis also found that quantitative information is communicated both quantitatively and qualitatively through these seven forms at each complexity level. Quantitative representations of quantitative information utilize numerals and/or words that signify specific quantities, as shown in Table 4.

Table 4

Numeracy Events Represented Quantitatively and Qualitatively

\begin{tabular}{|c|c|c|c|c|}
\hline & \multicolumn{2}{|c|}{ Quantitative Representations } & \multicolumn{2}{|c|}{ Qualitative Representations } \\
\hline & $\begin{array}{l}\text { Examples from maximum } \\
\text { complexity articles }\end{array}$ & $\begin{array}{c}\text { Examples from } \\
\text { minimum complexity } \\
\text { articles }\end{array}$ & $\begin{array}{c}\text { Examples from } \\
\text { maximum complexity } \\
\text { articles }\end{array}$ & $\begin{array}{c}\text { Examples from } \\
\text { minimum complexity } \\
\text { articles }\end{array}$ \\
\hline Comparisons & $\begin{array}{l}\text { "nearly } 38 \text { percent were } \\
\text { in deep poverty" }\end{array}$ & $\begin{array}{l}\text { "More than one-third } \\
\text { were deeply poor" }\end{array}$ & $\begin{array}{l}\text { "Quite a number were } \\
\text { less than thirteen." }\end{array}$ & $\begin{array}{l}\text { "For every } 100 \text { people, } \\
\text { only a small number } \\
\text { are poor." }\end{array}$ \\
\hline $\begin{array}{l}\text { Counts/ } \\
\text { Measures }\end{array}$ & $\begin{array}{l}\text { "The Census Bureau } \\
\text { tracks } 23 \text { different ethnic } \\
\text { groups." }\end{array}$ & $\begin{array}{l}\text { "The government } \\
\text { tracks } 23 \text { different } \\
\text { ethnic groups." }\end{array}$ & $\mathrm{X}$ & $\begin{array}{l}\text { "For generations, } \\
\text { Asian Americans have } \\
\text { lived ..." }\end{array}$ \\
\hline Arithmetic & $\begin{array}{l}\text { "210 people joined the } \\
\text { ranks of billionaires." }\end{array}$ & $\begin{array}{l}\text { "Take the poorer half } \\
\text { of the world's } \\
\text { population." }\end{array}$ & $\mathrm{X}$ & $\begin{array}{l}\text { "The number of Asian- } \\
\text { Americans is } \\
\text { increasing." }\end{array}$ \\
\hline Percentages & $\begin{array}{l}\text { "20.6 percent of } \\
\text { Americans were living at, } \\
\text { below, or just above the } \\
\text { federal poverty line." }\end{array}$ & $\begin{array}{l}\text { "About } 20 \text { percent of } \\
\text { Americans were } \\
\text { living close to the } \\
\text { federal poverty line." }\end{array}$ & $\mathrm{X}$ & $\begin{array}{l}\text { "They have low } \\
\text { percentages of } \\
\text { poverty." }\end{array}$ \\
\hline $\begin{array}{l}\text { Slope/ } \\
\text { Correlation }\end{array}$ & $\mathrm{X}$ & $\mathrm{X}$ & $\begin{array}{l}\text { "The number is } \\
\text { increasing alongside } \\
\text { the population." }\end{array}$ & $\begin{array}{l}\text { "Over time, his pay } \\
\text { goes up." }\end{array}$ \\
\hline Fractions & $\begin{array}{l}\text { "Nearly one-sixth of all } \\
\text { the employees are } \\
\text { children." }\end{array}$ & $\begin{array}{l}\text { "Nearly one in six of } \\
\text { all the workers are } \\
\text { children." }\end{array}$ & $\mathrm{X}$ & $\mathrm{X}$ \\
\hline Ranges & $\begin{array}{l}\text { "The majority are from } \\
\text { thirteen to sixteen." }\end{array}$ & $\begin{array}{l}\text { "Most are from } 13 \text { to } \\
\text { 16." }\end{array}$ & $\mathrm{X}$ & $\mathrm{X}$ \\
\hline
\end{tabular}


For instance, "210 people joined the ranks of billionaires" qualifies as a quantitative representation because the author provides a specific quantity (210) for readers to add to the existing population of billionaires. Conversely, qualitative representations of quantitative information utilize words that imply statistical trends or mathematical operations without providing specific quantities. This distinction can be seen in the example "The number of Asian-Americans is increasing." This excerpt similarly implies arithmetic through the word "increasing" but does not provide a specific quantity to add, prohibiting readers from conceptualizing the actual size of the population increase. Table 4 further outlines quantitative and qualitative representations of each form of numeracy event found in articles at the maximum and minimum complexity levels. An $X$ signifies that an example of the indicated numeracy event was not located in any of the five texts at the specified complexity level.

Though the rate of occurrence for comparisons exceeds those for counts/measures, percentages, and fractions, it is important to note that the identified comparisons utilize other mathematical forms to communicate inequalities. Table 5 displays the rates at which quantitative and qualitative comparisons appeared in the five texts at the maximum and minimum complexity levels, and the rates at which quantitative comparisons utilized counts, percentages, and fractions. Texts at the maximum complexity level presented readers with quantitative comparisons slightly more frequently $(58.8 \%)$ than qualitative comparisons (41.9\%), whereas texts at the minimum complexity level presented readers with qualitative comparisons much more frequently $(71.9 \%)$ than quantitative comparisons $(28.1 \%)$.

Like comparisons, analysis revealed that arithmetic is also represented quantitatively and qualitatively in texts at the maximum and minimum complexity levels. Similarly, quantitative representations of arithmetic utilize percentages and counts to provide readers with precise quantities to add, subtract, multiply, or divide. Table 6 displays examples of these different patterns of representation as well as the rates at which each occurred in texts at the maximum and minimum complexity levels. As with comparisons, quantitative representations of arithmetic occurred more frequently in texts at the maximum complexity level (62.1\%), whereas qualitative representations of arithmetic occurred more frequently in texts at the minimum complexity level $(70.0 \%)$. 
Table 5

Comparisons Represented Quantitatively and Qualitatively

\begin{tabular}{|c|c|c|c|}
\hline & $\begin{array}{l}\text { Number and rate of } \\
\text { occurrence in } \\
\text { maximum complexity } \\
\text { articles (74) }\end{array}$ & $\begin{array}{l}\text { Number and rate of } \\
\text { occurrence in } \\
\text { minimum complexity } \\
\text { articles (32) }\end{array}$ & Examples \\
\hline Quantitative & $43(58.1 \%)$ & $9(28.1 \%)$ & \\
\hline Counts & $25(58.1 \%)$ & $6(66.7 \%)$ & $\begin{array}{l}\text { "which can house up to } 10 \text { homeless and } \\
\text { foster children" }\end{array}$ \\
\hline Percentages & $12(27.9 \%)$ & $1(11.1 \%)$ & $\begin{array}{l}\text { "In Atlanta, for example, Asian-Americans } \\
\text { comprise just } 5 \text { percent } \text { of the population" }\end{array}$ \\
\hline Fractions & $6(14.0 \%)$ & $2(22.2 \%)$ & $\begin{array}{l}\text { "World's Richest } 85 \text { People Have as Much } \\
\text { as Half the Globe's Population" }\end{array}$ \\
\hline Qualitative & $31(41.9 \%)$ & $23(71.9 \%)$ & "Most students are not proficient" \\
\hline
\end{tabular}

Note: Seventy-four comparisons were identified in maximum complexity articles and 32 comparisons were identified in minimum complexity articles. Authors utilized other numeracy event forms including counts, percentages, and fractions when making quantitative comparisons.

Table 6

Arithmetic Represented Quantitatively and Qualitatively

\begin{tabular}{llll}
\hline \hline & $\begin{array}{c}\text { Number and rate of } \\
\text { occurrence in maximum } \\
\text { complexity articles }(29)\end{array}$ & $\begin{array}{c}\text { Number and rate of } \\
\text { occurrence in minimum } \\
\text { complexity articles }(10)\end{array}$ & Examples \\
\hline Quantitative & $18(62.1 \%)$ & $3(30.0 \%)$ & $\begin{array}{l}\text { "The Asian-American } \\
\text { population } \text { grew } 47 \text { percent." }\end{array}$ \\
Percentages & $14(77.8 \%)$ & $1(33.3 \%)$ & $\begin{array}{l}\text { "The wealth of the 1 percent } \\
\text { richest people in the world } \\
\text { amounts to \$110 trillion." }\end{array}$ \\
Counts & $4(22.2 \%)$ & $2(66.7 \%)$ & $\begin{array}{l}\text { "As he becomes more expert } \\
\text { the amount is increased" }\end{array}$ \\
Qualitative & $11(37.9 \%)$ & $7(70.0 \%)$ &
\end{tabular}

Note: Twenty-nine instances of arithmetic were identified in maximum complexity articles and 10 instances of arithmetic were identified in minimum complexity articles. Authors utilized other numeracy event forms including percentages and counts in quantitative representations of arithmetic. 


\section{Manual Simplification of Newsela Texts Results in Five Numeracy Event Outcomes}

Comparison of numeracy events across the four manually simplified texts revealed five outcomes. Numeracy events are maintained, changed, removed, added, and restored. Table 7 provides definitions and examples of each of these outcomes.

Table 7

Outcomes of Manual Simplification on Numeracy Events

\begin{tabular}{|c|c|c|c|}
\hline Outcomes & Definitions & \multicolumn{2}{|c|}{ Examples } \\
\hline Maintain & $\begin{array}{l}\text { The numeracy event is kept } \\
\text { the same when moving from } \\
\text { a more to less complex } \\
\text { iteration. }\end{array}$ & $\begin{array}{l}\text { "In the Midwest, the Asian-American } \\
\text { population grew } 47 \text { percent." }\end{array}$ & $\begin{array}{l}\text { "In the Midwest, the Asian-American } \\
\text { population grew } 47 \text { percent." }\end{array}$ \\
\hline Change & $\begin{array}{l}\text { A numeracy event that } \\
\text { existed in a more complex } \\
\text { iteration is changed or } \\
\text { modified in a less complex } \\
\text { iteration. }\end{array}$ & $\begin{array}{l}\text { "In Georgia and North Carolina that } \\
\text { population jumped more than } 80 \\
\text { percent." }\end{array}$ & $\begin{array}{l}\text { "Georgia and North Carolina grew the } \\
\text { fastest." }\end{array}$ \\
\hline Remove & $\begin{array}{l}\text { A numeracy event that } \\
\text { existed in a more complex } \\
\text { iteration is not included in a } \\
\text { less complex iteration. }\end{array}$ & $\begin{array}{l}\text { "In other words, a total of } 24,023 \text {, or } \\
\text { nearly one-sixth of all the employees } \\
\text { of the anthracite coal mines are } \\
\text { children." }\end{array}$ & $\begin{array}{l}\text { "In other words, nearly one-sixth of all } \\
\text { the employees of the coal mines are } \\
\text { children." }\end{array}$ \\
\hline Add & $\begin{array}{l}\text { A numeracy event that did } \\
\text { not exist in a more complex } \\
\text { iteration is added to a } \\
\text { simplified iteration. }\end{array}$ & $\begin{array}{l}\text { "The Asian-American population } \\
\text { grew faster in the South than any } \\
\text { other region of the country." }\end{array}$ & $\begin{array}{l}\text { "Asian-Americans were the fastest- } \\
\text { growing group in the South between } \\
2000 \text { and } 2010 \text {. Their population grew } \\
\text { faster in the South than any other part } \\
\text { of the country." }\end{array}$ \\
\hline Restore & $\begin{array}{l}\text { A numeracy event that was } \\
\text { initially removed in a more } \\
\text { complex iteration is restored } \\
\text { in a less complex iteration. }\end{array}$ & $\begin{array}{l}\text { "In Virginia, for example, the number } \\
\text { of Asian-Americans registered to vote } \\
\text { increased } 136 \text { percent from } 2004 \text { to } \\
\text { 2012. The number actually casting } \\
\text { ballots skyrocketed } 180 \text { percent." }\end{array}$ & 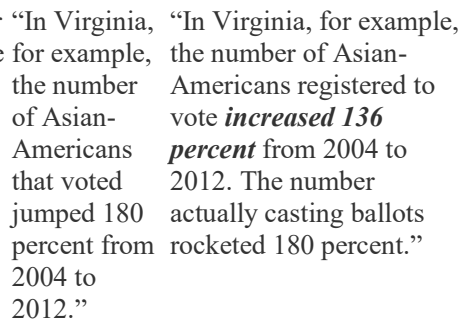 \\
\hline
\end{tabular}

Analysis revealed that these outcomes occurred at varying rates, depending on the round of simplification. Table 8 presents rates of occurrence for each outcome at each round of simplification or move. As text complexity decreased, the rate at which numeracy events were maintained decreased while the rate at which they were removed increased. The rate of change remained fairly consistent and fairly high, spiking slightly at Moves 2 and 3. Though uncommon, numeracy events were restored most frequently at Move 3 while added most frequently at Move 4. 
Table 8

Number and Rate of Occurrence for Outcomes at Each Round of Simplification or Move

\begin{tabular}{lcccc}
\hline \hline & Move 1 & Move 2 & Move 3 & Move 4 \\
\hline Maintain & $85(46.2 \%)$ & $62(39.7 \%)$ & $40(29.9 \%)$ & $14(12.1 \%)$ \\
Change & $69(37.5 \%)$ & $65(41.7 \%)$ & $56(41.8 \%)$ & $40(34.5 \%)$ \\
Remove & $28(15.2 \%)$ & $28(17.9 \%)$ & $29(21.6 \%)$ & $49(42.2 \%)$ \\
Add & $2(1.1 \%)$ & $0(0.0 \%)$ & $0(0.0 \%)$ & $10(8.6 \%)$ \\
Restore & $0(0.0 \%)$ & $1(0.6 \%)$ & $6(4.5 \%)$ & $3(2.6 \%)$ \\
Total & 184 & 156 & 134 & 116 \\
\hline \hline
\end{tabular}

Note: "Move 1" indicates the first round of simplification or the move from texts at the maximum Lexile level to the $1080-1180 \mathrm{~L}$ range. "Move 2" indicates the second round of simplification or the move from 1080-1180L to the 930$1130 \mathrm{~L}$ range. "Move 3 " indicates the third round of simplification or the move from the 930-1130L to the 730-950L range. "Move 4" indicates the final round of simplification or the move from 730-950L to the minimum Lexile level.

Numeracy events are changed in a variety of ways resulting from Newsela authors' manual simplification of texts. These changes, which are outlined in Table 9 , include word and syntax manipulations, making quantitatively represented numeracy events qualitative, numeracy event substitutions, and mode substitutions. Some changes alter the meaning of the original numeracy event while others preserve it.

Although readability formulae do not consider type, number, frequency, or complexity of numeracy events when rating text, the findings produced by this analysis suggest that Newsela writers still acknowledge these as challenges to comprehension. This is indicated by the differences in representational patterns found in articles at opposing ends of Newsela's complexity spectrum, as well as the varying rates at which strategies are applied at the different simplification moves. Though the same six numeracy event forms were found in all Newsela texts analyzed, articles classified as maximum complexity relied more heavily upon quantitative representations, whereas minimum complexity articles more frequently utilized qualitative representations of quantitative information. Additionally, though maintenance was the action most frequently applied to numeracy events during the first simplification move (46.2\%), change outpaced it during the second (41.7\%) and third moves (41.8\%), and removal became the most common action at the fourth move (42.2\%). These findings suggest that Newsela writers perceive numeracy events as challenging and therefore apply these editorial strategies to make the information embedded in mathematical texts more accessible to readers with varying skill sets and bases of prior knowledge. 
Table 9

Ways in Which Numeracy Events Are Changed

\begin{tabular}{|c|c|c|c|}
\hline \multirow{2}{*}{$\begin{array}{l}\text { Outcomes } \\
\text { Word } \\
\text { Manipulation }\end{array}$} & \multirow{2}{*}{$\begin{array}{l}\text { Definitions } \\
\text { 1. Substituting one word } \\
\text { for another. This includes } \\
\text { changes in parts of speech } \\
\text { and verb tense. }\end{array}$} & \multicolumn{2}{|c|}{ Examples } \\
\hline & & $\begin{array}{l}\text { "An overwhelming majority of the } \\
\text { slate-pickers are boys." }\end{array}$ & "Most of the slate-pickers are boys." \\
\hline & $\begin{array}{l}\text { 2. Adding a word or words } \\
\text { to contextualize the } \\
\text { numeracy event. }\end{array}$ & "The average is about 70 cents a day." & $\begin{array}{l}\text { "The average wage is about } 70 \text { cents a } \\
\text { day." }\end{array}$ \\
\hline \multirow[t]{5}{*}{$\begin{array}{l}\text { Syntax } \\
\text { Manipulation }\end{array}$} & 1. Adding phrases. & "Three-fourths hadn’t worked at all." & $\begin{array}{l}\text { "Three-quarters of the deeply poor } \\
\text { hadn't worked at all." }\end{array}$ \\
\hline & 2. Removing phrases. & $\begin{array}{l}\text { "Experts say that the number of } \\
\text { elderly Asian-Americans in the region } \\
\text { is increasing alongside the overall } \\
\text { population." }\end{array}$ & $\begin{array}{l}\text { "Experts say the number of elderly } \\
\text { Asian-Americans in the region is } \\
\text { increasing." }\end{array}$ \\
\hline & $\begin{array}{l}\text { 3. Dividing one sentence } \\
\text { into two or three sentences. }\end{array}$ & $\begin{array}{l}\text { (1) "But the Jennings School District } \\
\text { - serving about } 3,000 \text { students ..." }\end{array}$ & $\begin{array}{l}\text { (1) "The Jennings School District, } \\
\text { however, does all of these and more. } \\
\text { (2) It serves about } 3,000 \text { students ..." }\end{array}$ \\
\hline & $\begin{array}{l}\text { 4. Reducing two sentences } \\
\text { to one. }\end{array}$ & $\begin{array}{l}\text { (1) "Anecdotally, those who study the } \\
\text { population say the number of elderly } \\
\text { Asian-Americans in the region is } \\
\text { increasing alongside the overall } \\
\text { population, especially as a cheaper } \\
\text { cost of living draws retirees. (2) That } \\
\text { can mean increasing demand for elder } \\
\text { care, health care and similar issues can } \\
\text { pose challenges alongside a host of } \\
\text { others facing the community." }\end{array}$ & $\begin{array}{l}\text { (1) As the cheaper cost of living draws } \\
\text { retirees, an increasing demand for } \\
\text { elder care and health care can pose } \\
\text { challenges. }\end{array}$ \\
\hline & $\begin{array}{l}\text { 5. Changing sentence } \\
\text { structure. }\end{array}$ & $\begin{array}{l}\text { "One school district in Georgia has } \\
111 \text { different languages spoken } \\
\text { nearby." }\end{array}$ & $\begin{array}{l}\text { "There are } 111 \text { different languages } \\
\text { spoken near one Georgia school } \\
\text { district." }\end{array}$ \\
\hline $\begin{array}{l}\text { Made } \\
\text { Qualitative }\end{array}$ & $\begin{array}{l}\text { Replacing quantities with } \\
\text { mathematical words or } \\
\text { phrases. }\end{array}$ & $\begin{array}{l}\text { "In Georgia and North Carolina that } \\
\text { population jumped more than } 80 \\
\text { percent." }\end{array}$ & $\begin{array}{l}\text { "Georgia and North Carolina grew the } \\
\text { fastest." }\end{array}$ \\
\hline $\begin{array}{l}\text { Numeracy } \\
\text { Event } \\
\text { Substitutions }\end{array}$ & $\begin{array}{l}\text { One quantitatively } \\
\text { represented numeracy } \\
\text { event type is substituted } \\
\text { for another. }\end{array}$ & $\begin{array}{l}\text { "In Virginia, for example, the number } \\
\text { of Asian-Americans registered to vote } \\
\text { increased } 136 \text { percent from } 2004 \text { to } \\
\text { 2012. The number actually casting } \\
\text { ballots rocketed } 180 \text { percent." }\end{array}$ & $\begin{array}{l}\text { "Almost three times as many Asian- } \\
\text { Americans voted in Virginia in } 2012 \text {, } \\
\text { compared with 2004." }\end{array}$ \\
\hline $\begin{array}{l}\text { Mode } \\
\text { Substitutions }\end{array}$ & $\begin{array}{l}\text { One mode of } \\
\text { representation is } \\
\text { substituted for another. }\end{array}$ & $\begin{array}{l}\text { "According to the mining laws of } \\
\text { Pennsylvania, "no boy under the age } \\
\text { of fourteen shall be employed in a } \\
\text { mine, nor shall a boy under the age of } \\
\text { twelve be employed in or about the } \\
\text { outside structures or workings of a } \\
\text { colliery' (i.e., in a breaker)." }\end{array}$ & $\begin{array}{l}\text { "According to the mining laws of } \\
\text { Pennsylvania, no boy under the age of } \\
14 \text { shall be employed in a mine, nor } \\
\text { shall a boy under the age of } 12 \text { be } \\
\text { employed in a breaker." }\end{array}$ \\
\hline
\end{tabular}




\section{Discussion}

It is important to note that the texts analyzed in this study were not randomly selected. They were purposely chosen because they were known to contain several numeracy events which would facilitate the classification of representational patterns and the identification of strategies used during simplification moves. It is also important to note that the five texts analyzed in this study all came from Newsela's Literature Text Sets. These texts are curated for ELA teachers to assign to their students as supplemental reading alongside popular literary works. Thus, some findings of this study, particularly the prevalence of the various representational forms, may not be generalized to the broader corpus of Newsela texts, which also include informational texts curated to accompany social studies, science, and mathematics curricula. This study did not measure generalizability of the prevalence of mathematical forms. Instead, the goal was to explore how quantitative information is represented in Newsela articles as well as how those representations are manipulated for simplified iterations.

\section{Readers of Newsela Texts Need to Know Math}

The analysis of these texts revealed that authors use seven different numeracy event forms to represent quantitative information, meaning that even in non-mathematical disciplines, readers of Newsela texts must often possess, activate, and apply mathematical thinking. They must know the difference between counts, percentages, fractions, ranges, slopes, arithmetic, and comparisons so that when they encounter a number while reading, they can make an appropriate inference. Because these texts additionally employ qualitative representations of quantitative information, readers must also know that certain words, like "increased," and their synonyms, like "soared," "jumped," and "skyrocketed," signal that mathematical thinking is required.

\section{Numeracy Events Increase Text Complexity}

Although the inclusion of numeracy events may not factor into quantitative measures of text complexity, like Lexile, writers responsible for simplifying Newsela texts still perceive them as complex and take care to remove or modify them for simplified iterations. This is apparent in the different rates at which numeracy events appeared in the most and least complex text iterations. While 184 numeracy events were identified in the five articles at the maximum complexity level, only 68 were identified in the least complex iterations, meaning that well under half, or only about $37 \%$ of numeracy events were maintained from most to least complex text versions. 


\section{Even Simplified Versions Require Mathematical Knowledge}

Though readers of simplified iterations will encounter numeracy events less frequently than readers of more complex versions, they will still be exposed to them and therefore required to activate and apply mathematical thinking while reading in order to comprehend Newsela texts. Readers at both ends of the complexity spectrum will encounter six of the same numeracy event forms, which include comparisons, counts/measures, fractions, ranges, slope/correlation, and arithmetic, at almost the same rates, with the exception of percentages, which were scarcely found in texts at the minimum complexity level.

The primary difference between the numeracy event forms that appear in texts at the maximum and minimum complexity levels is the way in which they are represented. More complex text versions were found to present readers with quantitative representations of numeracy events at a greater rate while less complex text versions were found to present readers with qualitative representations more frequently. This means that Newsela's more complex texts contain more numeracy events that utilize precise quantities, such as "the 1 percent richest people," "95 percent of the post-crisis growth," and "increases topped 80 percent," while less complex texts contain more numeracy events that do not, such as "The very richest people," "almost all of the wealth," and "grew the fastest." Quantitative representations require greater mathematical knowledge and competence than qualitative representations. For instance, readers of the aforementioned quantitative representations will need to know the mathematical meaning of the word "percent" and apply it to the number and context provided to derive meaning.

While qualitative representations of numeracy events require less mathematical knowledge, they also offer readers less precision and accuracy than their quantitative equivalents. For example, while "almost all" and "95 percent" are often used interchangeably, "almost all" is much less explicit, leaving critical readers wondering "How much less than all?" Similarly, "increases topped 80 percent" provides readers with a precise quantity indicating the size of a population growth, whereas "grew the fastest" indicates that the growth of one population outpaced all others but, without specific quantities, readers are left to ponder "By how much?"

\section{Key Takeaways}

The results of this study indicate that although Newsela may be fulfilling its promise to increase access to information for a wider range of readers, that information may differ depending on readers' reading levels and the text iteration they read. Though changing and removing numeracy events may simplify text, it can also alter text meaning, resulting in vaguer and more imprecise information. 
Additionally, when students navigate outside of Newsela's simplification safety net and choose, or are assigned, to read informational texts directly from mainstream media outlets, they will most likely encounter quantitative representations of quantitative information, which will require them to activate mathematical knowledge to make meaning from specific quantities. Thus, teachers should strive to expose students to these representations, especially those who typically read less complex Newsela texts, which are less likely to contain them.

Although Newsela does not advertise that mathematical representations influence the readability ratings of their texts, the results of this analysis suggest that they do. Educators who use this platform, and who wish to see their students move up the readability ladder, should be aware of the various text features that influence complexity as well as the funds of knowledge that students must possess in order to access the full range of Newsela texts. In addition to developing this awareness, and also of equal importance, teachers can make visible for their students the more challenging text features, such as quantitatively represented numeracy events, by teaching them explicitly. ELA teachers, for instance, can partner with mathematics teachers or specialists to help students develop the numerical knowledge and skills required to comprehend more complex Newsela texts. Doing so will help all students, regardless of reading ability, assimilate this important cultural capital, which will facilitate their ability to construct meanings from complex, mathematical texts that are precise and accurate, while also enabling them to participate in dominant discourses within our highly quantified society.

\section{References}

Bernstein, Basil. 2000. Pedagogy, Symbolic Control, and Identity: Theory, Research, Critique. Vol. 5. Rowman \& Littlefield.

Bourdieu, Pierre. 2011. "The Forms of Capital." In The Sociology of Economic Life. Edited by Mark Granovetter \& Richard Swedberg. New York, NY: Routledge.

Burnard, Philip, Paul Gill, Kate Stewart, Elizabeth Treasure, and Barbara Chadwick. 2008. "Analysing and Presenting Qualitative Data." British Dental Journal 204, no. 8: 429-432. https://doi.org/10.1038/sj.bdj.2008.292 Carroll, John, Guido Minnen, Yvonne Canning, Siobhan Devlin, and John Tait. 1998. "Practical Simplification of English Newspaper Text to Assist Aphasic Readers." In Proceedings of the AAAI-98 Workshop on Integrating Artificial Intelligence and Assistive Technology, 7-10.

Chall, Jeanne. 2003. "Assessing Text Difficulty and Accessibility.” In Scaffolding Reading Experiences: Designs for Student Success, 2nd Ed. Edited by Michael F. Graves and Bonnie B. Graves. Norwood, MA: ChristopherGordon. 
Chandrasekar, Raman, and Bangalore Srinivas. 1997. "Automatic Induction of Rules for Text Simplification." Knowledge-Based Systems 10, no. 3: 183190. https://doi.org/10.1016/S0950-7051(97)00029-4

Chapman, Anne, and Alison Lee.1990. "Rethinking Literacy and Numeracy." Australian Journal of Education 34, no. 3: 277-289. https://doi.org/10.1177/000494419003400305

Cokely, Edward T., Mirta Galesic, Eric Schulz, Saima Ghazal, and Rocio GarciaRetamero. 2012. "Measuring Risk Literacy: The Berlin Numeracy Test." Judgment and Decision Making. https://doi.org/10.1037/t45862-000

Cunningham, James W., Elfrieda H. Hiebert, and Heidi Anne Mesmer. 2018. "Investigating the Validity of Two Widely used Quantitative Text Tools." Reading and Writing 31, no. 4: 813-833. https://doi.org/10.1007/s11145-017-9815-4

Dika, Sandra L., and Kusum Singh. 2002. "Applications of Social Capital in Educational Literature: A Critical Synthesis." Review of Educational Research 72, no. 1: 31-60. https://doi.org/10.3102/00346543072001031

Feng, Lijun. 2008. "Text Simplification: A Survey.” The City University of New York, Technical Report.

Fisher, Douglas, and Nancy Frey. 2015. "Selecting Texts and Tasks for Content Area Reading and Learning." The Reading Teacher 68, no. 7: 524-529. https://doi.org/10.1002/trtr.1344

Frith, Vera, and Robert Prince. 2009. "A Framework for Understanding the Quantitative Literacy Demands of Higher Education." South African Journal of Higher Education 23, no. 1: 83-97. https://doi.org/10.4314/sajhe.v23i1.44804

Fry, Edward. 2002. "Readability Versus Leveling." The Reading Teacher 56, no. 3: 286-291.

Kahan, Dan M., Ellen Peters, Maggie Wittlin, Paul Slovic, Lisa Larrimore Ouellette, Donald Braman, and Gregory Mandel. 2012. "The Polarizing Impact of Science Literacy and Numeracy on Perceived Climate Change Risks." Nature Climate Change 2, no. 10: 732-735. https://doi.org/10.1038/nclimate1547

Lareau, Annette, and Michèle Lamont. 1988. "Cultural Capital: Allusions, Gaps and Glissandos in Recent Theoretical Developments." Sociological Theory 6, no. 2: 153-168. https://doi.org/10.2307/202113

Lupo, Sarah M., John Z. Strong, and Kristin Conradi Smith. 2019. "Struggle Is Not a Bad Word: Misconceptions and Recommendations about Readers Struggling with Difficult Texts." Journal of Adolescent \& Adult Literacy 62, no. 5: 551-560. https://doi.org/10.1002/jaal.926 
National Center for Educational Statistics. n.d. "What Does the NAEP Reading Assessment Measure?" National Assessment of Educational Progress, accessed January 1, 2019.

National Governors Association Center for Best Practices, Council of Chief State School Officers. 2010. "English Language Arts Standards: Introductions: Key Design Considerations" Common Core State Standards Initiative, accessed December 21, 2018. Retrieved from http://www.corestandards.org/ELA-Literacy/introduction/key-designconsideration/.

Newsela. n.d. “Collections,” accessed June 17, 2019. https://newsela.com/aboutcollections.

Oakes, Jeannie, Adam Gamoran, and Reba Neukom Page. 1992. "Curriculum Differentiation: Opportunities, Outcomes, and Meanings." In Handbook of Research on Curriculum edited by Phillip W. Jackson, 570-608. Washington, DC: American Educational Research Association.

O’Halloran, Kay. 2008. Mathematical Discourse: Language, Symbolism and Visual Images. A\&C Black.

Petersen, Sarah E., and Mari Ostendorf. 2007. "Text Simplification for Language Learners: A Corpus Analysis.” In Workshop on Speech and Language Technology in Education.

Reyna, Valerie F., Wendy L. Nelson, Paul K. Han, and Nathan F. Dieckmann. 2009. "How Numeracy Influences Risk Comprehension and Medical Decision Making." Psychological Bulletin 135, no. 6: 943. https://doi.org/10.1037/a0017327

Scarton, Carolina, Gustavo Paetzold, and Lucia Specia. 2018. "Text Simplification from Professionally Produced Corpora." In Proceedings of the Eleventh International Conference on Language Resources and Evaluation (LREC 2018).

Shreiner, Tamara L. 2018. "Data Literacy for Social Studies: Examining the Role of Data Visualizations in K-12 Textbooks." Theory \& Research in Social Education 46, no. 2: 194-231. https://doi.org/10.1080/00933104.2017.1400483

Siddharthan, Advaith. 2014. "A Survey of Research on Text Simplification.” ITLInternational Journal of Applied Linguistics 165, no. 2: 259-298. https://doi.org/10.1075/itl.165.2.06sid

Steen, Lynn Arthur, ed. 2001. Mathematics and Democracy: The Case for Quantitative Literacy. NCED.

Street, Brian, and Dave Baker. 2006. "So, What About Multimodal Numeracies." In Travel Notes from the New Literacy Studies: Instances of Practice, edited by Kate Pahl \& Jennifer Rowsell, 219-233. Clevedon, England: Multilingual Matters. https://doi.org/10.21832/9781853598630-012 
Thomas, David R. 2006. “A General Inductive Approach for Analyzing Qualitative Evaluation Data." American Journal of Evaluation 27, no. 2: 237-246. https://doi.org/10.1177/1098214005283748

Thorne, Sally. 2000. "Data Analysis in Qualitative Research." Evidence-based Nursing 3, no. 3: 68-70. https://doi.org/10.1136/ebn.3.3.68

Wolska, Magdalena, and Yulia Clausen. 2017. "Simplifying Metaphorical Language for Young Readers: A Corpus Study on News Text." In Proceedings of the 12th Workshop on Innovative Use of NLP for Building Educational Applications, 313-318. https://doi.org/10.18653/v1/W17-5035 